\title{
DA PROIBIÇÃO À REVOLUÇÃO NA PRODUÇÃO LITERÁRIA ESCRITA POR MULHERES: O CASO DE CLARA E ALBA EM A CASA DOS ESPÍRITOS, DE ISABEL ALLENDE
}

Danielly Cristina Pereira Vieira Rafael Macário de Lima

Resumo: Na obra A Casa dos Espíritos (2017[1982]), de Isabel Allende, destacam-se as mulheres da família, principalmente Clara e Alba, as responsáveis pela narração da história - a primeira por escrevê-la em seus cadernos de anotar a vida e a segunda por resgatar essa escrita, após sua libertação do cárcere ditatorial, e narrá-la de modo a construir a obra. Nessa perspectiva, nosso objetivo é analisar o potencial revolucionário e de resistência da escrita das mulheres utilizando como corpus a obra de Allende. Para isso, através de teóricas como Joanna Russ (2018), Gerda Lerner 2019, Michelle Perrot (2019) e Virginia Woolf (2019), faremos um breve percurso acerca da proibição e dos empecilhos históricos impostos às mulheres a fim de barrar ou dificultar suas expressões através da escrita, culminando nas estratégias utilizadas por elas, tal como a escrita de cartas e, como Clara, de diários/cadernos privados, como estratégia de registro e de voz. Concluímos que Allende, em sua obra, ilustra o poder revolucionário da produção escrita das mulheres.

Palavras-chave: Escrita de Mulheres. Autoria de mulheres. Isabel Allende. Diário. Escrita privada.

Abstract: In Isabel Allende's A Casa dos Espíritos (2017 [1982]), the women of the family, especially Clara and Alba, stand out and are responsible for telling the novel's story - the first by writing her thoughts in her journals and the second by rescuing this writing, after her release from the dictatorial prison, and narrating it in order to create the book. In this perspective, our objective is to analyze the revolutionary and resistant potential of women's writing through Allende's book. For this, through theorists such as Joanna Russ (2018), Gerda Lerner 2019, Michelle Perrot (2019), and Virginia Woolf (2019) we will undertake a brief journey about the prohibition and the historical obstacles imposed to women to stop or hinder their writing expressions, culminating in the strategies used by them to overcome these obstacles, such as writing 
letters and, like Clara, private journals as strategies for being vocal and register thoughts. We conclude that Allende, in her work, illustrates the revolutionary power of women's written production.

Keywords: Women's writing. Literature by women. Isabel Allende. Journal. Private writing.

\section{INTRODUÇÃO}

Teóricos/teóricas, professores/professoras, e críticos e críticas literários são constantemente questionados acerca da necessidade e dos usos que a literatura tem para à sociedade. Afinal, qual a serventia da literatura? As respostas para essa pergunta são um compilado de clichês e um extenso debate teórico que vem sendo construído há décadas. Todos são válidos, todavia, acreditamos que a literatura é uma extensão da experiência humana, cuja função pode ser descrita como a de humanizar e revolucionar. Certamente essa máxima não se aplica a toda obra literária, contudo, se aplica a A Casa dos Espíritos (2017), de Isabel Allende. Eis a explicação: humanização, pois apresenta uma das facetas mais perversas da humanidade, a face cruel do autoritarismo patriarcal, e torna-se uma ferramenta de denúncia; revolução por sua narrativa corajosa que engaja uma luta contra essa mesma força. As heroínas dessa narrativa humanizadora são as mulheres, materializadas em uma genealogia da cor branca: Nivea, Clara, Blanca e Alba. Uma revolução escrita, narrada e protagonizada por mulheres. 
O presente estudo tem como objetivo central apresentar para o leitor uma dimensão histórica/teórica acerca dos percalços da mulher, no que diz respeito a seu direito à escrita. Para tanto, criamos um percurso que se inicia com as questões de proibição perpassando por algumas práticas que abordam as impossibilidades de produção de escrita por mulheres, caminhando em um segundo momento pelos empecilhos, até o processo de revolução, utilizando o texto de Isabel Allende A Casa dos Espíritos (2017) como objeto de análise literária, no qual, será ser apresentado como se deu o processo de emancipação/revolução das mulheres Trueba, por meio de um testamento literário. Dessa maneira, esse artigo se insere dentro de um quadro, no qual será apresentado como a literatura pode e é uma forma de revolução feminina. Uma escrita que reverbera em uma genealogia, aqui, matriarcal.

\section{A PROIBIÇÃO}

Alguns estudiosos, como Leonard Shlain (1999), entendem que o desenvolvimento da escrita funcionou como um elemento substancial da cultura patriarcal. Shlain (1999), por exemplo, exemplifica com a perspectiva de como um texto escrito, nomeadamente o Antigo Testamento, um dos primeiros textos alfabéticos que se conhece, tem sua 
função primordial a de doutrinar os indivíduos, constituindose enquanto um dos textos mais poderosos da história da humanidade ao fundamentar três poderosas religiões patriarcais - o cristianismo, o judaísmo e o islamismo. Para o escritor, a ascensão do poderio bíblico encerra a transição entre o pensamento antigo de adoração das deusas, e a caracterização demonizada do feminino. Desse modo, para o escritor, juntamente à produção escrita utilizada na construção dessa imagem negativa das mulheres, a proibição ao acesso à escrita pelas mulheres impossibilitou a produção de um contra-argumento por séculos.

É sabido, no entanto, que, desde a Antiguidade, existiram mulheres que foram minunciosamente instruídas. Entretanto, Gerda Lerner (2019) salienta, em primeiro lugar, como essa não era uma realidade comum às mulheres das mais diversas civilizações; em segundo lugar, essa educação almejava a utilização dessa integrante família enquanto informantes em casamentos diplomáticos; e, por fim, como o poder máximo dessas mulheres estaria atrelado ao seu desempenho sexual perante o marido detentor do poder econômico e social. Além disso, Lerner (2019) aponta como essa prática mingou paralelamente ao desenvolvimento do Estado.

Gerda Lerner (2019) aponta como essa crescente exclusão das mulheres dos ambientes de ensino era justificado pela 
parcela masculina da sociedade com base nas diferenças biológicas entre os corpos. Para esses homens, segundo a historiadora, o ciclo menstrual, o gestar, o parir e menopausa eram entendidas como anomalias incapacitantes para atividades que exigissem intelecto, condição esta reforçada negativamente quando referidas às mulheres de classes e raças não dominantes. Sarah Jane Aiston (2010) aponta, por exemplo, que, no século $X X$, opositores à permissão do ensino formal às mulheres defendiam que o ensino acadêmico as tornaria assexuadas.

Percebe-se, desse modo, a existência de uma associação primária do feminino como essencialmente inferior. Sobre essa perspectiva, Virginia Woolf (2019) disserta em um artigo de 1864:

Em 1864, a Saturday Review expressou com toda clareza o que os homens receavam quanto às mulheres e o que precisavam delas. A ideia de submeter jovens senhoritas a exames na universidade local 'é quase de tirar o folego', dizia o articulista. Se tivessem de ser examinadas, seria preciso providenciar que os examinadores fossem 'eruditos de idade avançada', e que as esposas presumivelmente idosas desses senhores idosos ocupassem 'uma posição de destaque na galeria'. Mesmo assim, seria 'quase impossível convencer o mundo de que uma bela mulher obteve suas honras de maneira justa'. Pois, escrevia o crítico, a 
verdade era que 'há um instinto masculino forte e inextirpável de que uma jovem culta ou mesmo talentosa é o monstro mais intolerável de toda a criação'. (WOOLF, 2019, p. 58-59)

Com o argumento de Woolf (2019) pode-se entender como os corpos das mulheres foram posicionados em primeiro plano devido à impossibilidade da existência de méritos intelectuais e a própria abominação masculina à mera possibilidade de uma mulher formalmente educada. Desse modo, percebe-se a existência de uma conjuntura arquitetada para manter as mulheres distantes da possibilidade de contra-argumentação: sendo entendidas como incapazes, as mulheres foram proibidas de ter acesso ao ensino formal; no entanto, é por serem, há milênios, privadas da educação formal que as mulheres, por gerações, foram incapazes de se manterem social e economicamente. Assim, algo construído historicamente adquire uma imagem naturalizada. Nesse ponto, Virginia Woolf (2019) questiona um contemporâneo defensor dessa perspectiva:

Então, como Falcão Afável [pseudônimo de um autor que Woolf contesta] explica o fato que me salta aos olhos, e imagino que aos olhos de qualquer observador imparcial, de que o século XVII gerou um maior número de mulheres notáveis do que o século XVI, o século XVIII mais do que o XVII, e o XIX mais do que os três somados juntos? [...] 
Para explicar a ausência completa não só de boas, mas também de más escritoras, não consigo conceber nenhuma razão a não ser alguma restrição externa a suas capacidades. Pois Falcão Afável admite que sempre existiram mulheres com capacidade de segunda ou terceira categoria. Por que, a não ser que estivessem forçosamente proibidas, não expressaram esses talentos na literatura, na música ou na pintura? [...] Pode ele apontar um único nome entre os grandes gênios da história que tenham surgido entre um povo privado de educação e mantido na submissão [...]? Parece-me inquestionável que Shakespeare pode existir porque tem predecessores em sua arte, porque faz parte de um grupo que discute e pratica a arte em liberdade, porque ele mesmo tem grande liberdade de ação e experiência. Talvez em Lesbos as mulheres pudessem gozar dessas condições, mas desde então nunca mais foi o caso. (WOOLF, 2019, p. 40-49)

Nesse ponto, Woolf (2019) argumenta sobre o abismo temporal entre a produção de Safo e as primeiras grandes mulheres escritoras a partir do século XVII, apontando como, em paralelo outros obstáculos impostos socialmente à liberdade das mulheres, a proibição do acesso ao ensino formal seria o responsável pela quase inexistência de produções literárias escritas por mulheres em todos esses séculos. 
É interessante pontuar como Virginia Woolf insistia nessa argumentação no início do século XX e como Betty Friedan em 1963, com o seu A Mística Feminina, ainda necessita retomá-la, enquanto que Mary Wollstonecraft já defendia o acesso da mulher à educação formal no século XVIII, através da publicação do seu Reivindicação dos direitos da mulher, em 1792. O argumento da teórica é simples aos olhos atuais, mas revolucionário para sua época, ao defender a necessidade de se entender as mulheres como os seres humanos que são e, portanto, com possibilidades e desejo de se desenvolverem.

Nesse ponto, realçamos como mesmo após a extinção da proibição do acesso ao ensino formal por parte das mulheres, para além do gênero, outros recortes, como raça e classe, e outras estruturas seguiram impactando negativamente na produção literária das mulheres. Abordaremos esse tema no tópico seguinte.

\section{OS EMPECILHOS}

A teórica e escritora Joanna Russ (2018) descreve a existência de uma articulação social enviesada e dissimulada que difunde a perspectiva da incapacidade das mulheres de serem escritoras a fim de mantê-las em silêncio e, ao mesmo tempo, age de modo a atrapalhar e depreciar as 
mulheres que, ainda assim, produzem. A partir dessa perspectiva, a autora lista alguns métodos utilizados pelos críticos literários para a manutenção dessa estrutura.

Primeiramente, Russ (2018) fala acerca da proibição informal da escrita das mulheres: educação proibida e, posteriormente, pouco acesso; pobreza; dependência econômica; responsabilidade doméstica e familiar; quando trabalhadora, falta de tempo livre devido as longas jornadas de trabalho; o constante desencorajamento; quando o superavam, não eram levadas a sério; além da necessidade de perfeição para serem, no mínimo, consideradas. Esse pensamento pode ser visto, como destaca Russ (1983) no discurso do pai de Virgínia Woolf que afirmava uma incapacidade feminina da escritora de construir heróis verdadeiramente masculinos, invalidando a percepção da filha.

Em seguida, outro método seria o da negação da agência. Nesse aspecto, as estratégias variavam entre a simples negação, associando a obra a um homem, como ocorreu com Woolf, que foi acusada de contratar um estudioso para escrever seus trabalhos; passando pela negação da feminilidade com argumentos de que "o homem dentro dela" teria escrito ou que, em outro extremo, alguém "mais 
do que uma mulher" teria escrito, como ocorreu com Sylvia Plath, por exemplo; chegando na ideia de que a própria história teria "se escrito sozinha", a associando a algum plot já escrito.

A ideia da mácula da agência também foi utilizada, isto é, a perspectiva de que sim, a mulher escreveu, mas não deveria. Nesse método, o pensamento era o de que uma mulher virtuosa jamais teria conhecimentos acerca da vida suficientes para escrever uma boa obra, portanto, se a escreveu é por não ser virtuosa. Esse julgo sofreu, como destaca Russ (2018), Charlotte Brontë pelo seu Jane Eyre que recebeu diversas críticas que a consideraram uma obraprima caso escrita por um homem, mas que, tendo sido escrita por uma mulher, seria chocante e repugnante.

Outro método de supressão da escrita de mulheres foi a crítica ao conteúdo. Esse método consistia basicamente em menosprezar a produção unicamente com base nas temáticas abordadas, transparecendo como os aspectos da vida associados às mulheres eram considerados inferiores e desviantes, sendo a masculinidade a norma. Além disso, associava a escrita unicamente ao que a mulher autora experenciou, negando sua capacidade de abstração. Por fim, existiria o julgo de ininteligível/mal escrito que, na 
verdade, era o indicativo do não entendimento masculino acerca do que era narrado.

A estratégia da falsa categorização, por sua vez, segue sendo utilizada até a atualidade, consistindo em não nomear as mulheres por seus nomes e pela sua profissão, mas sim como mães/irmãs/amantes de alguém tido como mais importante ou com sua irrestrita associação a termos reducionistas e inferiorizantes como puta, suicida, esposa, especificações da nacionalidade, regionalista, etc.

Por fim, a autora destaca o método do isolamento, isto é, quando, após ultrapassar todas essas barreiras, a escritora consegue espaço no cânone, mas a atenção voltase exclusivamente para o trabalho em questão, criando a imagem da "autora de um livro só"; e, o último método, o da anomalia, isto é, a constante marginalização da obra que, mesmo tendo entrado no cânone, é tida como fora do eixo, não pertencendo a tradição em questão e, portanto, excluídas de antologias, compilações, livros didáticos, etc.

Da aplicação desses métodos, o esperado é o silêncio. Nesse ponto, Michelle Perrot (2019) aponta a existência de outros artifícios utilizados para o silenciamento das mulheres, tal como a gramatica que tende a tudo neutralizar no masculino. A historiadora também destaca a frequência 
com que a produção escrita das mulheres é destruída, seja por negligência, seja pela própria autora, já que, "convencidas de sua insignificância, estendendo à sua vida passada o sentimento de pudor que Ihes havia sido inculcado, muitas mulheres, no ocaso de sua existência, destruíam ou destroem - seus papéis pessoais" (PERROT, 2019, p. 22). Acerca dessa produção, Perrot disserta:

É uma escrita privada, e mesmo íntima, ligada à família, praticada à noite, no silêncio do quarto, para responder às cartas recebidas, manter um diário e, mais excepcionalmente, contar sua vida. Correspondência, diário íntimo, autobiografia não são gêneros especificamente femininos, mas se tornam mais adequados às mulheres justamente por seu caráter privado. De maneira desigual.

Há poucas autobiografias de mulheres. Por quê? O olhar voltado para si, numa fase de mudança ou ao final de uma vida, mais frequentemente em pessoas públicas que querem fazer o balanço de sua existência e marcar sua trajetória, é uma atitude pouco feminina. 'Minha vida não é nada', diz a maioria das mulheres. Pra que falar dela? (2019, p. 28)

Fica nítido, com esse fragmento, que o desprestígio associado à vida das mulheres encontra-se tão arraigado na sociedade que elas mesmas, muitas vezes, absorvem tal conceito, seguindo o caminho do silenciamento esperado. No entanto, Perrot (2019) assinalada como a produção epistolar 
serviu como um veículo profícuo de expressão das mulheres por séculos, especialmente pela autorização social, graças ao seu caráter doméstico. Nas palavras de Perrot:

A correspondência, entretanto, é um gênero muito feminino. Desde Mme. de Sévigné, ilustre ancestral, a carta é um prazer, uma licença, e até um dever das mulheres. As mães, principalmente, são as epistológrafas do lar. Elas escrevem para os parentes mais velhos, para o marido ausente, para o filho adolescente no colégio interno, a filha casada, as amigas de convento. Suas epístolas circulam eventualmente pela parentela. A carta constitui uma forma de sociabilidade e de expressão feminina, autorizada, e mesmo recomendada, ou tolerada. Forma distanciada do amor, mais conveniente e menos perigosa do que o encontro, a carta de amor toma o lugar do próprio amor, a ponto de representar o essencial. Torna-se um tema e um motivo da literatura (no romance epistolar) e da pintura de gênero, principalmente a pintura holandesa. A mulher que lê uma carta em seus aposentos, ou perto de uma janeira, na fronteira entre o interior e o exterior, sonha com o amante ou o marido viajante ou guerreiro. [...]

A destruição e o anonimato ameaçam as cartas pessoais. Paula Cossart publicou recentemente uma correspondência amorosa, de relações adúlteras, aproximadamente mil e quinhentas cartas, encontradas quase por acaso nos Arquivos de Paris. É um testemunho excepcional sobre o sentimento e as práticas amorosas do século XIX, num casal da burguesia intelectual romântica cujo ideal é a vida conjugal. (2019, p. 29) 
Nesse ponto, nota-se a relevância para análise social das produções privadas enquanto fontes acerca do comportamento de certos grupos, inseridos em um determinado tempo e realizadores de uma determinada ação que, em muitos aspectos, pode refletir as nuances do seu recorte social. Seguindo esse mesmo raciocínio, Michelle Perrot (2019) salienta o valor dos diários:

A escrita do diário era um exercício recomendado, principalmente pela Igreja, que o considerava um instrumento de direção de consciência e de controle pessoal. O mesmo ocorria com os protestantes. [...] O diário ocupa um momento limitado, mas intenso, na vida de uma mulher, interrompido pelo casamento e pela perda do espaço íntimo. Está ligado ao quarto das meninas. Por um breve tempo permite a expressão pessoal.

Esses diversos tipos de escritos são infinitamente preciosos porque autorizam a afirmação de um 'eu'. É graças a eles que se ouve o 'eu', a voz das mulheres. (2019, p. 29-30)

Apesar da produção referida por Perrot (2019) ter sido produzia majoritariamente por mulheres educadas, consequentemente, pertencentes a classes sociais privilegiadas que permitiam o acesso delas à escrita mesmo que de caráter pessoal, destaca-se a relevância desses registros por serem alguns dos poucos momentos 
de autorrepresentação possível para as mulheres em contraposição à abundância dos estereótipos e imposições presentes nos discursos masculinos

Acerca disso, concordamos com Michelle Perrot quando esta salienta a necessidade de, sobrepondo-se às produções que falam sobre as mulheres, se investigar as obras de suas autorias para "transpor, com elas, os obstáculos que, durante tanto tempo, impediram seu acesso à escrita, fronteira proibida do saber e da criação [...]" (PERROT, 2019, p. 31). É necessário então romper com a proibição de outrora, e acessar aquilo que ficou oculto. As produções de escrita feminina estão permeadas pelos tempos. Elas estão nas fraturas, em pequenas fendas, espremidas entre os laços temporais, empoeiradas; é necessário restituir o local de direito dessas escritas, abrir baús antigos, soprar a poeira, para que assim, possamos começar a ouvir o silêncio das que falaram pelo papel. O nosso objeto de análise, neste estudo, é fruto do testemunho ficcionalizado de Isabel Allende; é fruto da narração e das personagens femininas; é fruto da história que vem à tona no momento no qual Alba abre os baús e encontra os diários da avó.

\section{A REVOLUÇÃO E O CASO DE CLARA E ALBA}

Um romance monumental como A Casa dos Espíritos (2017) evoca diversas discussões para o campo da crítica 
literária, pois há diversos temas dentro do romance que podem ser esmiuçados dentro do processo da crítica, como por exemplo: o fato de ser um romance histórico, elementos de erotismo com o personagem francês, realismo mágico, tempo narrativo, romance memorialista. E a lista poderia continuar, todavia, haja vista o processo teórico construído nesse estudo, é fundamental que nossa leitura esteja voltada para o caso das personagens femininas desse romance: Clara, Blanca e Alba, como também a autora: Isabel Allende, pois, como mencionado anteriormente, a obra também é, para além da ficção, um testemunho de Allende. Nesse ponto, Michelle Perrot aponta que:

A história é o que acontece, a sequência dos fatos, das mudanças, das revoluções, das acumulações que tecem o devir das sociedades. Mas é também o relato que se faz de tudo isso. [...] As mulheres ficaram muito tempo fora desse relato, como se, destinadas à obscuridade de uma inenarrável reprodução, estivessem fora do tempo, ou pelo menos, fora do acontecimento. Confinadas no silêncio de um mar abissal. (2019, p. 16)

Desse modo, para além da importância histórica do relato de Allende, há o peso dessa escrita ocorrer através de uma perspectiva de uma mulher, o que tende a focalizar elementos negligenciados tanto na história quanto na literatura, por 
envolverem questões tipicamente associadas ao universo dito feminino. Nessa perspectiva, cresce o interesse pelos estudos do doméstico e de suas produções por serem entendidos, conforme mencionado anteriormente, como registros de uma perspectiva frequentemente ignorante, mas extremamente valiosa.

Primeiramente, acerca do universo histórico, A Casa dos Espíritos (2017), de Isabel Allende, se circunscreve dentro da história da literatura latino-americana como uma narrativa contundente que narra um Chile sanguinário, patriarcal e autoritário com um pano de fundo fantástico que somente a pessoa de Isabel Allende poderia realizar, haja vista ela ser uma parente próxima de Salvador Allende (presidente deposto e supostamente assisando pelos militares durante o golpe no Chile). Desse modo, de forma alegórica, Allende (2017) narra a história do Chile do século XX através da saga da família Trueba através do patriarca e da geração de mulheres. Há, portanto, transpassadas na narrativa de Allende, diversas dores: a dor de ser mulher, a dor de ser chilena e dor de ser uma testemunha de uma tragédia familiar.

Para além desse dado pessoal acerca da autora, os grandes triunfos da narrativa de Allende estão cristalizados em três 
escolhas narrativas: o espaço da narrativa (O Chile); o foco narrativo em contraponto entre as personagens femininas (Clara, Blanca e a narradora Alba) e a personagem masculina (Esteban Trueba, o patriarca e também narrador); o pano de fundo de ascensão de um governo autoritarista (a ascensão de Pinochet); a perspectiva social e historicamente lúcida, mas transpassadas pelo realismo mágico; e, portanto, a sensível amálgama entre ficção e realidade. Esses são os elementos que compõem a narrativa de A Casa dos Espíritos (2017); elementos esses que estão unidos, ou melhor, amontoados um sob o outro, como um grande palimpsesto, cujo contraste contra o sol ilumina todas as camadas de escrita sobrepostas, contribuindo, assim, para uma história única, porém multifacetada, com uma espécie de fluidez labiríntica. Essa miscelânia está presente tanto no encadeamento das histórias, quanto no ambiente mágico presente desde a infância de Clara, até sua morte, quando a balança da narrativa começa a inclinar-se mais para a questão histórica de modo mais realista. É possível afirmar que a balança realismo-mágico/ ficção versus realismo/História, em grande parte do livro, faz paralelo com a balança feminino versus masculino. Esse paralelismo pode ser visto em passagens como "Clara era muito precoce e tinha a transbordante imaginação herdada, via materna, por todas as mulheres da família" (ALLENDE, 
2017, p. 12), em "Clara especulava a respeito do fato de que, se as loucuras se repetem na família, deve ser porque existe uma memória genética que impede que se percam no esquecimento" (ALLENDE, 2017, p. 189) e em "[...] [Blanca] dava-se conta de que suas angústias noturnas eram fruto da imaginação febril que herdara de sua mãe e se tranquilizava até que voltassem a cair as sombras da noite e recomeçasse seu ciclo de espanto" (ALLENDE, 2017, p. 277); por sua vez, a herança Trueba se aproxima, principalmente, da violência que vai ganhando força primeiro através de Esteban Trueba, e, em seguida, através de uma aura coletiva quando este entra na política paralelamente à ascensão do governo ditatorial.

Em segundo lugar, sobre o aspecto doméstico, percebese a relevância da casa na obra, principalmente quando relacionada a figura de Clara. Na perspectiva ocidental burguesa, como aponta Susan Strehle (2008), a ideia do lar tende a estar revestido por uma aura de proteção e acomodação das mulheres em oposição ao movimento e à violência do mundo público. Essa, por certo tempo, foi a realidade do casarão da esquina, no qual "nos tempos em que Clara estava viva, quando Alba era ainda uma criança, a grande casa da esquina era um mundo fechado, onde ela cresceu protegida até dos seus próprios pesadelos" 
(ALLENDE, 2017, p. 287). Além disso, é evidente como o casarão da esquina mostra-se como uma entidade viva não através da ornamentação afetada encomendada por Esteban Trueba, mas pela existência de Clara que o toma como refúgio, como local de trabalho espiritual e como local de escrita. No entanto, Strehle (2008) destaca os estudos atuais que passam a enxergar o lar como um local de exercício de poder. Nesse ponto, Clara não escapa da violência doméstica sendo espancada por Esteban Trueba. A violência sofrida é simbólica na obra por reposicionar Clara em um local de silêncio para com o marido, quando os silêncios anteriores, já costumeiros da personagem, se deram por uma completa satisfação com a vida, já que, anteriormente, "Clara viveu esse período ocupada em suas fantasias, acompanhada pelos espíritos do ar, da água e da terra, tão feliz, que não sentiu a necessidade de falar durante nove anos" (ALLENDE, 2017, p. 94-95).

Em outra perspectiva, Clarissa Pinkola Estés (2014) apresenta um viés psicanalítico que posiciona o lar como um ponto de natural retorno das mulheres. Para Estés, retornar ao lar:

É a capacidade de encontrar, à luz do sol ou nas trevas, nossa terra natal. Todas nós sabemos voltar para casa. [...] Ele fica em um local interno, um lugar em algum ponto 
do tempo, não do espaço, onde a mulher se sinta inteira. [...] Ela vai porque chegou a hora, e por isso precisa ir. (2014, p. 324-326)

Desse modo, torna-se simbólico perceber o vínculo espacial, sim, já que Alba, neta de Clara, permanece no casarão da esquina, mas, principalmente, temporal, através da retomada dos escritos da avó. Nesse ponto, se torna essencial perceber que a narrativa de A Casa dos Espíritos (2017) começa apresentando uma informação fundamental para compreensão do romance. Para além do elemento curioso que é o animal de estimação de Clara, o estranho cachorro Barrabás, o romance é iniciado com a narradora declarando de onde aquelas informações foram retiradas: os cadernos de Clara. Sendo assim, o texto abre com a informação para o leitor de que, ali, há um processo de resgate das memórias de uma família por meio dos diários, ou cadernos de anotar a vida, da personagem Clara, já apresentando como a narrativa será fundacionada:

'Barrabás chegou à família por via marítima', anotou a menina Clara com a sua delicada caligrafia. Já nessa altura tinha o hábito de escrever as coisas importantes e, mais tarde, quando ficou muda, escrevia também as trivialidades, sem suspeitar que cinquenta anos depois os seus cadernos me iriam servir para resgatar a memória do passado e sobreviver ao meu próprio espanto. $\mathrm{O}$ dia 
em que chegou Barrabás era Quinta-Feira Santa. (ALLENDE, 2017, p. 9)

Alba, neta de Clara, então, assume a incumbência de ser a divulgadora da história de sua avó e, consequentemente, a narradora da história de sua mãe e dela mesma em um processo de se entender por meio da história de sua família. A ato de iniciar o romance indicando que a história ali narrada foi retirada dos diários de Clara é desenhar para o leitor/ leitora um percurso que caminhará para em uma progressão narrativa, ou seja, uma sucessão de fatos que indicam um começo e um fim, mas, que, ao mesmo tempo, através da conexão entre as linhas que percorrem as vidas das mulheres dessa família, emaranha a perspectiva tanto da narradoraneta, quanto da narradora-primeira-avó por se apresentar de forma cíclica em um movimento que tanto avança quanto retoma o passado. A narrativa, então, é iniciada e finalizada por meio da experiência de Clara e de sua cosmovisão, o romance é finalizado ao encontrar os diários de Clara, uma retomada a narrativa que dá o pontapé inicial ao romance:

Minha avó escreveu durante 50 anos nos seus cadernos de anotar a vida. Escamoteados por alguns espíritos cúmplices, salvaram-se por milagre da pira infame em que pereceram tantos outros papéis da família. Tenho-os aqui, aos meus pés, amarrados com fitas coloridas, separados por acontecimentos, 
e não por ordem cronológica, tal como ela os deixou antes de partir. Clara escreveuos, a fim de que agora me servissem para resgatar as coisas do passado e sobreviver ao meu próprio espanto. O primeiro é um caderno escolar de 20 folhas, escrito com uma delicada caligrafia infantil. Começa assim: 'Barrabás chegou à família por via marítima...' (ALLENDE, 2017, p. 462)

Percebe-se como a escrita é o fio condutor tanto do romance, quanto da vida dessas mulheres, já que os cadernos de Clara serviriam tanto para a escrita do romance em si, quanto para "resgatar as coisas do passado e sobreviver ao meu próprio espanto" (ALLENDE, 2017, p. 462). Além disso, outra passagem que indica a existência dessa relação é o momento da morte de Clara:

Clara escreveu pequenos cartões para seus entes queridos, que eram muitos, e escondeu-os numa caixa sob sua cama. $\mathrm{Na}$ manhã seguinte não se levantou e, quando a empregada entrou com o dejejum, não Ihe permitiu abrir as cortinas. Começara a despedir-se também da luz para lentamente entrar nas sombras. [...]

Pouco antes do fim, Clara recuperou a consciência e pode falar com tranquilidade. A primeira coisa que notou foi a mão de Alba entre as suas.

- Vou morrer, não é verdade, filhinha? perguntou.

- Sim, vovó, mas não importa, porque eu estou ao seu lado - respondeu a menina. 
- Está bem. Pegue uma caixa de cartões que está debaixo da cama e distribui-os, pois não vou conseguir despedir-me de todos. (ALLENDE, 2017, p. 312-314)

Percebe-se como a relação da avó com a neta através da escrita já se iniciava ainda na infância da menina, quando esta torna-se o mensageiro encarregado de distribuir os cartões escritos em segredo, no seu quarto, por Clara. Acreditamos que essa relação é fundamental para compreender a importância da experiência das mulheres dentro da narrativa. A escrita de Clara, através de cadernos, diários e cartões é seu modo de perpetuar a história através da sua experiência de vida e da sua voz, os quais reúnem todas as suas alegrias e as suas dores: a morte de sua irmã, seus poderes, seu silêncio, seu casamento, seu marido, filhos, filha e neta. Memórias narradas e deixadas em registro, como um testemunho do que era ser uma mulher como ela durante aquele período - haja vista que a personagem Clara é atravessada por diversos privilégios como o de raça e classe, o que a posicionava em um local específico de privilégio, embora não cego para as mazelas da sociedade, além de não estar isenta à violência e dominação masculina. Assim, o ato de leitura e propagação das memórias da avó, realizada por Alba, é certamente um dos atos que comunga 
com as postulações realizadas por Michelle Perrot (2019), e já discutidas neste estudo. $\mathrm{O}$ ato de escrever e registrar sua história é um ato de privilégio de Clara, haja vista que ela tivera educação formal e tinha acesso a diversos meios de escrita, como mencionado no romance "Clara lia muito" (ALLENDE, 2017, p. 87). Entretanto, também é um ato válido de autorrepresentação e uma forma de propagar a sua voz e de registrar a história de uma família de mulheres. Assim, além da experiência da mulheridade presente nas narrativas, também o fato de Isabel tomar a caneta e papel para narrar, tornam-se um exercício de transpor as barreiras, para relembrar a fala de Michelle Perrot (2019) trazida no tópico anterior.

A Casa dos Espíritos (2017) é, antes de mais nada, uma narrativa sobre mulheres, narrada por uma mulher e escrita por uma mulher. Autorrepresentação é certamente uma das peças-chave para expandir nossa compreensão com esse romance. O romance narra a história de Clara, e, por meio dela através do olhar da sua neta Alba, conhecemos todas aqueles que estavam dentro do seu círculo familiar. O romance é registrado como um dos frutos do realismo mágico/literatura fantástica da literatura latino-americana, haja vista os poderes de Clara e sua comunhão com o 
místico. Esse elemento é inserido dentro da narrativa com muita naturalidade e sem grandes explicações, Clara, é a Clarividente e essa é uma informação apresentada ao leitor sem explicações paranormais, ela é apresentada com muita naturalidade dentro da narrativa, um elemento típico das narrativas de realismo mágico latino-americanas. Clara e seus poderes, tornam-se então o ponto central da narrativa, ela "visualiza e profetiza" a morte de sua irmã Rosa, visualiza seu casamento com o antigo pretendente da falecida e, consequentemente, casa-se com Esteban Trueba.

Por fim, Esteban Trueba é certamente o contraponto necessário do romance. Pode-se dizer que é o antagonista, porém, há um pequeno arco de redenção na história de Esteban. Como já mencionado, o romance é perpassado pelas dores do feminino perante uma violência e uma dominação masculina, e essa, certamente é a marca desse personagem. Esteban casa-se com Clara, constrói fortuna, mas a custo de marcas de sangue. Como traços típicos do coronelismo latino, Esteban estupra mulheres e enche suas terras de filhos bastardos, tortura funcionários, estabelece regimes análogos a escravidão, é um agressor e assume uma postura anticomunista. Posteriormente, esses elementos o levam a ser Senador do Chile e apoiar o golpe de Pinochet. A função 
de Esteban dentro do romance é de materializar as mazelas da dominação masculina corroborando para estabelecer como esse tipo de masculinidade está fundado dentro dos problemas da sociedade e consequentemente, os problemas que as mulheres sofrem. A agressividade do personagem, mascarada como amor e cuidado, sua hipocrisia por uma família justa e respeitável enquanto suas terras estavam cheias de filhos nascidos de sua violência, são marcas típicas de um tipo social de homem, cuja violência é a sua única forma de linguagem.

Em contrapartida, Allende posiciona Clara com autonomia, como um ser inalcançável em seu íntimo por Esteban:

Observando-a com o nariz corado pelo vendo e rindo por qualquer pretexto, Esteban jurou a si próprio que mais cedo ou mais tarde ela acabaria por amá-lo tal como ele necessitava de ser querido, ainda que para consegui-lo tivesse que empregar os recursos mais extremos. Davase conta que Clara não lhe pertencia e que, se ela continuava habitando um mundo de aparições, de mesas de três pés que se mexem sozinhas e de baralhos em que se vê o futuro, o mais provável era de que nunca chegasse a lhe pertencer. A despreocupada e impudica sensualidade de Clara também não lhe bastava. Desejava muito mais do que o seu corpo; queria apoderar-se daquela matéria imprecisa e luminosa que havia no seu interior e Ihe escapava ainda 
nos momentos em que ela parecia morrer de prazer. (ALLENDE, 2017, p. 108-109)

E também:

Lembro-me de que começava a assediá-la ao cair da noite. À tarde ela se sentava para escrever, e eu fingia saborear o cachimbo, mas, na realidade eu a espiava de rabo de olho. Mal desconfiava de que ia deitarse - porque começava a limpar a pena e a guardar os cadernos - eu me adiantava. la claudicando até o banheiro, lavava-me, penteava-me, vestia um roupão atoalhado cor de vinho, que comprara para seduzi-la, mas de cuja existência ela nunca pareceu se dar conta, ficava de ouvido colado à porta e esperava-a. Quando a ouvia avançar ao longo do corredor, atacava-a. Tentei tudo, desde cobri-la de carícias e presentes até ameaçá-la de derrubar a porta e moê-la a bengaladas, mas nenhuma dessas opções resolvia 0 abismo que nos separava. (ALLENDE, 2017, p. 196)

Ao construir um personagem como Esteban Trueba em uma narrativa permeada por mulheres, Isabel Allende aponta como as provações e percalços sofridos por essas personagens foram causados por um homem. Esteban tornase, então, o contraponto de Clara, enquanto a narrativa o projeta como causador das mazelas dessas mulheres e seus infortúnios, Clara é o bálsamo e ponte com um processo de amor e respeito. Há, portanto, o primeiro antagonista dessas 
mulheres, materializado nesse pater famílias que assume um processo de dominação sobre essas mulheres. Se há um processo de dominação masculina, há um processo de resistência feminina, e certamente o processo de escrita por Clara é um processo de resistência.

Resistência essa visível em todas as companheiras de cárcere de Alba e nela mesma, e alegorizada na obra com a idosa que a resgata após sua libertação pelo regime ditatorial:

Ficamos conversando o resto da noite. Era uma daquelas mulheres estoicas e práticas do nosso país, que têm um filho de cada homem que passa por suas vidas e que, além disso, recolhem em seu lar as crianças que outros abandonam, os parentes mais pobres e qualquer pessoa que necessite de uma mãe, uma irmã, uma tia, mulheres que são o pilar central de muitas vidas alheias, que criam filhos para vê-los ir embora depois e que também veem seus homens partirem, sem se permitir um queixume, porque têm outras urgências maiores com que se ocupar. Pareceu-me igual a tantas outras que conheci nos refeitórios populares, no hospital do meu tio Jaime, no vicariato, onde iam perguntar por seus desaparecidos, no necrotério, onde iam buscar seus mortos. Disse-lhe que se tinha arriscado muito ao ajudar-me, e ela sorriu. Então, eu soube que o coronel Garcia e outros como ele têm os seus dias contados, porque não tinham conseguido destruir o espírito dessas mulheres. (ALLENDE, 2017, p. 458-459) 
O trecho acima, é um exemplo de como há um processo de escuta e fala das mulheres, apresentando seu processo de resistência, no caso acima, ao encarceramento. Dessa maneira, o romance é permeado de uma polifonia de vozes femininas que estão em um estado combatente, um estado atravessado pelos mais diversos processos de opressão. 0 pano de fundo histórico, no qual a história está inserida - o Golpe Militar Chileno de 1973 - é retrato por Allende dentro de sua rede de ficção, como já havíamos mencionado. Estão, então, retratados diversos processos de perda e luto; o choro das mulheres encarceradas, a perda de filhos e filhas. 0 processo ditatorial foi de sangue e lágrimas, todavia, houve também um processo de resistência, e segundo $A$ Casa dos Espíritos (2017), houve uma resistência feminina. Allende triunfa ao narrar o as pequenas angústias, o choro anônimo, a perda pisada. A Casa dos Espíritos (2017), torna-se, então, a representação ficcionalizada não só da voz, como do grito de uma legião de mulheres.

\section{CONCLUSÃO}

Lembrar, escrever e perpetuar. Esses três verbos sintetizam o processo acerca da necessidade de escritos como esse, como também do texto de Isabel Allende: lembrar o passado, escrever para que não seja esquecido 
e perpetuar para que seja apreendido. Neste estudo, enveredamos pela história das mulheres passando por uma das mazelas por elas sofridas: a negação da escrita pelo sistema patriarcal. Estabelecendo um caminhar pelas suas implicações e suas as dores, e em A Casa dos Espíritos (2017), reconhecemos esse processo por meio da relação da personagem Clara e como sua força se manifesta dentro da narrativa, tornando-se o ponto de triunfo da narrativa, ou seja, tudo acontece por meio de seu olhar, por meio de seus frutos, seja sua prole ou sua escrita. Nessa narrativa familiar tivemos o processo de ficcionalização da memória, revestir a realidade com literatura. Como por exemplo, o enterro de Pablo Neruda, que falece pós queda de Salvador Allende é narrado com primor. Ocultando o nome do Vencedor do Nobel de Literatura simplesmente pelo termo Poeta, no texto de Isabel Allende, tomamos sua mão e caminhamos pelos rastros de um mundo de outrora, conhecemos os personagens desprezíveis e o olhar acalentador de Clara, a Clarividente, e de como sua filha e neta são forças femininas baseadas no outrora, desdobramentos dela mesma. Nessa perspectiva, aprendemos que a literatura faz pequenas revoluções diariamente, e que ela ainda está a serviço da humanização. Pelos menos assim nós esperamos que seja. 


\section{REFERÊNCIAS}

AISTON, Sarah. Women, Education, and Agency, 1600-2000: An Historical Perspective. In: SPENCE, J; AISTON, S (Eds.). Women, education, and agency, 1600-2000. Nova York; Londres: Routledge e Taylor \& Francis Group. 2010.

ALLENDE, Isabel. A casa dos espíritos. São Paulo: Mediafashion, 2017. ESTÉS, Clarissa. P. Mulheres que correm com os lobos. Mitos e histórias do arquétipo da Mulher Selvagem. Rio de Janeiro: Rocco, 2014.

FRIEDAN, Betty. Mística feminina. Petrópolis: Editora Vozes Limitada, 2020.

LERNER, Gerda. A criação do Patriarcado: História da Opressão das Mulheres pelos Homens. São Paulo: Cultrix. 2019.

PERROT, Michelle. Minha história das mulheres. São Paulo: Contexto, 2019.

RUSS, Joanna. How to suppress women's writing. Austin: University of Texas Press, 2018.

SHLAIN, Leonard. Alphabet versus the goddess: the conflict between word and image. Londres: Peguim/Compass, 1999.

STREHLE, Susan. Transnational Women's Fiction. Unsettling Home and Homeland. Nova York: Palgrave Macmillan, 2008.

WOLLSTONECRAFT, Mary. Reivindicação dos direitos da mulher. São Paulo: Boitempo, 2016.

WOOLF, Virginia. Profissões para mulheres e outros artigos feministas. Porto Alegre: L\&PM, 2019.

\section{Danielly Cristina Pereira Vieira}

Doutoranda em Letras - Teoria da Literatura na UFPE, sendo bolsista CNPq.

E-mail: daniellycpvieira@gmail.com

Lattes: https://lattes.cnpq.br/4538906962596512 


\section{Rafael Macário de Lima}

Doutorando em Teoria da Literatura, pela UFPE.

É membro do Grupo de Pesquisa "Derivações e Representações Interartísticas das Vozes do Atlântico", na linha de Estudos em Literatura, Memória e Imaginário.

E-mail: rafsmacario@gmail.com

Lattes: http://lattes.cnpq.br/3280325337804042

ORCID iD: https://orcid.org/0000-0002-8117-3311 